\author{
MONIKA A. KRÓL ${ }^{1}$
}

\title{
Zadania samorządu terytorialnego w zakresie prawnej ochrony powierzchni ziemi
}

\section{Wprowadzenie}

Wzrost znaczenia problemów związanych z ochroną środowiska, poprzez ich wieloaspektowy charakter w życiu społecznym i gospodarczym, spowodował, iż realizacja obowiązków w tym zakresie stała się jednym z zadań współczesnego państwa $^{2}$. Zadania odnoszące się do ochrony środowiska służą urzeczywistnieniu celów ogólnospołecznych i związane są z zapewnieniem temu społeczeństwu podstawowych warunków egzystencji, właściwych pod względem ekologicznym warunków jego rozwoju, czy szerzej bezpieczeństwu ekologicznemu. Wyrazem przyjęcia tych założeń jest postanowienie zawarte w art. 74 ust. 1 i 2 Konstytucji Rzeczypospolitej Polskiej³.

Rozszerzanie się potrzeb społecznych doprowadza współcześnie do tego, że znaczna ich część, m.in. w zakresie ochrony środowiska, nie może być zaspokajana inaczej, jak tylko zbiorowo, przez urządzenia społeczne ${ }^{4}$. Funkcje tego typu nazywane są integracyjnymi, gdyż zapewniają egzystencję społeczeństwa jako całości. Zakres takich zadań w ostatnich dekadach ulega gwałtownemu rozszerzeniu, a ich wykonanie zaczyna być odczuwane przez społeczeństwo jako jedna z głównych funkcji państwa ${ }^{5}$. Realizacja tych funkcji jest w zasadzie niezależna od ustroju państwa, łączących go powiązań międzynarodowych czy stopnia jego zamożności. Wskazane czynniki, zwłaszcza ekonomiczne, mają jednak istotny wpływ na wybór

$1 \quad$ Uniwersytet Łódzki.

2 Taki pogląd prezentowano w doktrynie od połowy lat 70. XX w.: L. Łustacz, Rola państwa i prawa w ochronie środowiska,, (w:) Prawo a ochrona środowiska, L. Łustacz (red.), Ossolineum 1975, s. 97 i tenże, Rola polityki i prawa w kształtowaniu i ochronie środowiska, (w:) „Studia luridica”, t. II. Zagadnienia prawnej ochrony środowiska naturalnego, wyd. Uniwersytetu Warszawskiego 1974, s. 9 oraz L. Jastrzębski, Prawo ochrony środowiska w Polsce, Warszawa 1980, s. 58, a także M. Górski, Rola państwa w ochronie środowiska, „Organizacja. Metody. Technika" 1990, z. 8-9, s. 10-13.

3 Ustawa z dnia 2 kwietnia 1997 r. Konstytucja Rzeczypospolitej Polskiej, Dz.U. nr 78, poz. 483 ze zm., dalej: „Konstytucja RP”.

4 Por. J. Starościak, Zagadnienia przemian administracji państwa socjalistycznego, (w:) Studia z dziedziny prawa administracyjnego, L. Bar (red.), Ossolineum 1971, s. 68-69.

5 Pisał już o tym w latach 80. XX w. L. Jastrzębski, Prawo ochrony..., op. cit., s. 58. 
realizowanych zadań ochronnych czy ich zakres ${ }^{6}$. Przedstawione powyżej cechy, charakteryzujące działalność państwa w dziedzinie ochrony środowiska, powodują traktowanie tej działalności jako odrębnej funkcji państwowej

Funkcje państwa w zakresie ochrony środowiska są realizowane przez aparat administracyjny. Stąd też funkcje organów administracji publicznej, wywodzone z funkcji państwa, są określane jako organizowanie bezpośredniej, praktycznej realizacji funkcji państwa ${ }^{8}$. Istotne jest przy tym, że w odróżnieniu od szeregu innych zadań państwowych, działalność w dziedzinie ochrony środowiska nie może być skutecznie realizowana tylko przez wydzieloną część aparatu państwowego. Ze względu na różnorodne aspekty problemu, w rozwiązanie jego musi być zaangażowany cały system organów państwowych, rządowych i samorządowych. Jak wskazano w literaturze ${ }^{9}$, ochrona środowiska jest od $1990 \mathrm{r}$. jednym z podstawowych obszarów aktywności samorządu terytorialnego, jego organiczną funkcją, wektorem wyznaczającym kierunki działań jednostek.

Niniejsze badania służą analizie zadań powierzonych jednostkom samorządu terytorialnego $\mathrm{w}$ rozwiązywaniu kwestii związanych $\mathrm{z}$ ochroną powierzchni ziemi i podziału zadań ochronnych pomiędzy trzy szczeble ${ }^{10}$ samorządu. Pojawia się też zagadnienie badawcze dotyczące przyjętych przez ustawodawcę kryteriów tego podziału i ich optymalność.

\section{Ochrona środowiska jako zadanie organów administracji publicznej}

Zadania administracji $\mathrm{w}$ zakresie ochrony środowiska narastały stopniowo w miarę rozszerzania się realnego zagrożenia, powodowanego głównie ze strony działalności człowieka. Powierzanie kolejnych zadań określonym jednostkom administracyjnym było rezultatem ujawnionych zjawisk, i jak wskazywał E. Smoktunowicz ${ }^{11}$, uświadomienia sobie przez organy państwowe konieczności przeciwstawienia się procesom niszczącym poszczególne elementy środowiska.

$6 \quad$ Wskazywał to szerzej M. Górski, Rola państwa..., op. cit., s. 10-13.

$7 \quad$ L. Łustacz, Rola państwa..., op. cit., s. 98.

8 J. Borkowski, Określenie administracji i prawa administracyjnego, (w:) System prawa administracyjnego, J. Starościak (red.), t. I, Wrocław 1977, s. 56.

9 P. Wilczyński, Ochrona środowiska jako samodzielna funkcja administracji samorządowej, (w:) P. Korzeniowski, I. Wieczorek (red.), Reglamentacja korzystania ze środowiska jako funkcja administracji samorządowej, Łódź 2018, s. 28.

10 Przez określenie „szczebel” przyjmuję cechę trójstopniowości jednostek samorządu terytorialnego, z pełnym uwzględnieniem wzajemnych niezależności tych jednostek i braku hierarchii, szerzej J. Zimmermann, Prawo administracyjne, Warszawa 2018, s. 274, czy H. Izdebski, Samorząd terytorialny. Podstawy ustroju i działalności, Warszawa 2014, s. 130.

11 E. Smoktunowicz, Podział ról wśród organów administracji państwowej w zakresie ochrony zasobów i tworów przyrody, „Studia Prawno-Ekonomiczne” 1973, t. XI, s. 7. 
Współcześnie podstawą prawną wyznaczenia działań organów administracji publicznej w zakresie ochrony środowiska są przepisy Konstytucji $\mathrm{RP}^{12}$. Należy do nich art. 5, który zobowiązał państwo do ochrony środowiska w oparciu o zasadę zrównoważonego rozwoju, a obowiązek ten statuuje wśród fundamentalnych dla egzystencji państwa wartości. Konkretyzacją ogólnej zasady odpowiedzialności państwa za stan środowiska, w stosunku do władz publicznych, jest art. 74 ust. 1 i 2 Konstytucji $\mathrm{RP}^{13}$, zobowiązujący do prowadzenia polityki zapewniającej bezpieczeństwo ekologiczne. W przepisie tym wskazane zostały funkcje państwa oraz zasadnicze kierunki i cele jego działania, z których wynikają konkretne kompetencje i zadania organów państwa w ogóle, zwłaszcza tych, które wymienia sama Konstytucja, a zatem także samorządu terytorialnego. Konsekwencją powyższych regulacji jest konstatacja, że ochrona środowiska jest obowiązkiem władz publicznych, od którego nie mogą się uwolnić1 ${ }^{14}$.

Uznanie powyższego obowiązku i fundamentalnego charakteru zasad ochrony środowiska jest podstawą do przyjęcia środków prawnych umożliwiających jego realizację w stosunku do poszczególnych elementów środowiska, w tym także powierzchni ziemi. Nakaz prowadzenia polityki przez władze publiczne w taki sposób, aby mogła następować realizacja celu ogólnego ochrony środowiska, dotyczy polityki tych władz, odnoszącej się do całości życia gospodarczego i społecznego. Jak wskazuje M. Górski ${ }^{15}$, podejście to pozwoliło na skonstruowanie powszechnie uznanej zasady określającej sposób podejścia do problemów ochrony środowiska, nazywanej zasadą kompleksowości ochrony, uwidocznionej w art. 11 Traktatu o funkcjonowaniu Unii Europejskiej ${ }^{16}$, a mającej odzwierciedlenie w art. 5 ustawy Prawo ochrony środowiska ${ }^{17}$.

Osiągnięcie integracji w realizacji celów ekologicznych, ekonomicznych i społecznych wymaga konieczności wypracowywania kompromisu między zapewnieniem ochrony środowiska, rozwojem kraju a naturalnymi podstawowymi warunkami bytu narodu. Cele te muszą być traktowane jako współzależne i muszą być osiągnięte tylko dzięki zintegrowanemu podejściu do postępu gospodarczego, roz-

12 Określenie celów państwa w dziedzinie ochrony środowiska w tekście konstytucji postulował M. Górski, Wydawanie aktów administracyjnych jako prawna forma dopuszczenia do korzystania z zasobów środowiska - propozycje de lege ferenda, „Studia Prawno-Ekonomiczne” 1994, t. L. s. 22, a w doktrynie niemieckiej: H. Steiger, Określenie celów państwa a ustawa zasadnicza. Z problematyki najnowszego rozwoju politycznego i prawno-konstytucyjnego RFN, „Acta Universitatis Lodziensis. Folia luridica” 1988, nr 36, s. 23-49.

13 Szerzej: M. Górski, Komentarz do art. 74 Konstytucji RP, (w:) M. Safjan, L. Bosek (red.), Konstytucja RP. Komentarz, t. I, Art. 1-86, s. 1700-1701 oraz M. Derlatka, L. Garlicki, Komentarz do art. 74 Konstytucji RP, (w:) L. Garlicki, M. Zubik (red.), Konstytucja Rzeczpospolitej Polskiej. Komentarz, t. II, Warszawa 2016, s. 801-808.

14 J. Boć, (w:) J. Boć (red.), Konstytucje Rzeczypospolitej oraz komentarz do Konstytucji RP z 1997 roku, Wrocław 1998, s. 134-135.

15 M. Górski, W poszukiwaniu modelu administrowania sprawami ochrony środowiska, (w:) Między tradycją a przyszłością w nauce prawa administracyjnego. Księga jubileuszowa dedykowana Profesorowi Janowi Bociowi, J. Supernat (red.), Wrocław 2009, s. 178.

16 Wersja skonsolidowana, Dz.Urz. UE C 326 z 26.10.2012 r., s. 47 i n.

17 Ustawa z dnia 27 kwietnia 2001 r. Prawo ochrony środowiska, tekst jedn. z 2018 r., poz. 799 ze zm., dalej: „p.o.ś.” 
woju społecznego, ale z uwzględnieniem pojemności ekologicznej ekosystemów ${ }^{18}$. Przykładem przyjęcia takiej koncepcji są założenia wspierania polityki rozwoju, uregulowane w ustawie o zasadach prowadzenia polityki rozwoju ${ }^{19}$. W celu realizacji polityki rozwoju przyjęto zespół wzajemnie powiązanych działań realizowanych w celu zapewnienia trwałego i zrównoważonego rozwoju kraju oraz spójności społeczno-gospodarczej i terytorialnej, w skali krajowej, regionalnej lub lokalnej, w szczególności w zakresie ochrony środowiska, rozwoju obszarów wiejskich, ale i wspierania rozwoju przedsiębiorczości, wzrostu gospodarczego czy zwiększania konkurencyjności gospodarki. Politykę tę na poziomie regionalnym i lokalnym prowadzą wszystkie szczeble samorządu terytorialnego (art. 2 u.z.p.p.r.). Organy samorządu terytorialnego prowadzą politykę ochrony środowiska na podstawie strategii rozwoju, programów i dokumentów programowych, jak również za pomocą wojewódzkich, powiatowych i gminnych programów ochrony środowiska (art. 14 ust. 1 i 2 p.o.ś.).

Zadania służące ochronie środowiska należą do większości organów administracji publicznej, ale niektóre spośród tych organów zostały powołane wyłącznie lub przede wszystkim do wykonywania takich zadań albo zadania te stanowią istotną część ich zakresu działania ${ }^{20}$. Zadania te są bardzo rozbudowane, a ich merytoryczny zakres został podzielony na zadania $\mathrm{w}$ zakresie zarządzania środowiskiem i zadania wykonawcze ${ }^{21}$. Zadania określone w sposób ogólny w stosunku do środowiska obciążają całość administracji publicznej, natomiast w stosunku do jego poszczególnych elementów, m.in. powierzchni ziemi, muszą być konkretyzowane ze wskazaniem określonych szczebli aparatu i oznaczeniem organów, co gwarantować ma prawidłowość i skuteczność ich wykonania.

\section{Kryteria podziału zadań z zakresu ochrony środowiska}

Aktualnym problemem pozostaje kwestia powierzenia poszczególnych zadań odpowiednim organom administracji publicznej. Jak wskazuje P. Wilczyński ${ }^{22}$, repartycja zadań z zakresu ochrony środowiska między administrację rządową oraz przekazanie tych zadań jednostkom samorządu terytorialnego dokonuje się m.in. w oparciu o zasadę pomocniczości, zasadę domniemania właściwości samorządu terytorialnego oraz zasadę podstawowego charakteru gminy jako jednostki samorzą-

18 Environmental principles and concepts, OCDE/GD(95)124, OECD Paris 1995, s. 5, czy Global Environmental Outlook GEO4 - Environment for development, UNEP 2007, s. 100.

19 Ustawa z dnia 6 grudnia 2006 r. o zasadach prowadzenia polityki rozwoju, tekst jedn. z 2018 r., Dz.U. poz. 1307 ze zm., dalej: „u.z.p.p.r.”

20 E. Smoktunowicz, Encyklopedia obywatela PRL, Warszawa 1987, s. 402.

21 M. Górski, Zarządzanie sprawami ochrony środowiska, (w:) M. Górski (red.), Prawo ochrony środowiska, Warszawa 2018, s. 99-100.

22 P. Wilczyński, Ochrona środowiska..., op. cit., s. 28. 
du terytorialnego. Do wskazanych kryteriów trzeba także dodać zasadę realizacji interesu publicznego.

Nie podejmując próby rozstrzygnięcia konstytucyjnych wątpliwości co do charakteru prawnego zasady pomocniczości ${ }^{23}$, należy podkreślić, że zasada ta, jako zasada ustrojowa ${ }^{24}$, współcześnie odgrywa rolę w całym prawie administracyjnym. Jest jedną z podstawowych zasad kształtujących organizację państwa i struktur ponadpaństwowych, a także podział zadań wykonywanych przez organy tychże struktur $^{25}$. Zasada pomocniczości jest ściśle związana z zasadą decentralizacji władzy w państwie ${ }^{26}$. Można stwierdzić, że postępujący w pierwszej dekadzie XXI w. proces decentralizacji administracji był przejawem realizacji tej zasady.

Zasada pomocniczości odnosi się również do relacji między poszczególnymi jednostkami samorządu terytorialnego. Jak wskazuje M. Stahll ${ }^{27}$, przeprowadzenie rozgraniczenia zadań publicznych pomiędzy terenową administrację rządową a samorząd terytorialny utrudnia to, że każda sprawa publiczna i każde zadanie publiczne mieści w sobie moment podwójnego zainteresowania - ze strony całości reprezentowanej przez państwo i ze strony grupy miejscowej. Lokalność jest bowiem cechą stopniowalną. Autorka podkreśla, że samorządowi należy przekazywać te zadania, przy których lokalność przeważa, tj. takie, którymi najbardziej są zainteresowane wspólnoty samorządowe najlepiej znające potrzeby swoich członków ${ }^{28}$.

Ponadto, jak podkreślono w doktrynie ${ }^{29}$, zasada pomocniczości jest zasadą dynamiczną i elastyczną jednocześnie, jest zawsze relatywna i zmienna, wymaga kontekstu aksjologicznego, co w konsekwencji nie wprowadza sztywnego podziału zadań pomiędzy poszczególne szczeble administracji publicznej. Z jej pomocą nie można ustalić konkretnych zadań, które będą przypisane państwu albo społeczeń-

Szerzej: I. Lipowicz, (w:) J. Boć (red.), Konstytucje Rzeczypospolitej..., op. cit., s. 43; K. Complak, (w:) J. Boć (red.), Konstytucje Rzeczpospolitej..., op. cit., s. 12-13 oraz E. Olejniczak-Szałowska, (w:) M. Stahl (red.), Prawo administracyjne. Pojęcia, instytucje, zasady w teorii i orzecznictwie, Warszawa 2016, s. 177-178.

24 T. Rabska, Pozycja samorządu terytorialnego w konstytucji, „Ruch Prawniczy, Ekonomiczny i Socjologiczny” 1995, z. 2, s. 41-57. Por. na ten temat: M. Radwan, Zasada pomocniczości w polityce regionalnej EWG, „Samorząd Terytorialny" 1993, z. 9, s. 12 i n. i M. Stahl, Samorząd terytorialny a państwo, (w:) M. Stahl, E. OlejniczakSzałowska, Samorząd terytorialny, Podstawowe zagadnienia, Warszawa 1994, s. 42 oraz M. Swora, Organizacje pozarządowe a samorząd terytorialny (zagadnienia wybrane), (w:) M. Górski, M. Stahl, J.P. Tarno (red.), Administracja i prawo administracyjne u progu trzeciego tysiąclecia, Materiały konferencji naukowej katedr prawa i postępowania administracyjnego, Łódź 2000, s. 455, a także J. Regulski, Nowy ustrój, nowe szanse, nowe problemy, (w:) Materiały Szkoleniowe RAP, z. 1, s. 18-19, czy B. Dolnicki, Koncepcja województwa samorządowego, „Samorząd Terytorialny" 1999, z. 6, s.18-19.

25 M. Górski, W poszukiwaniu modelu..., op. cit., s. 179.

26 J. Zimmerman, Prawo administracyjne..., op. cit., s. 168.

27 M. Stahl, Zakres działania gmin - zagadnienia ogólne, (w:) M. Stahl (red.), Administracyjnoprawne zadania i kompetencje gmin, Warszawa 1994, s. 10.

$28 \quad$ Ibidem, s. 10.

29 M. Kulesza, Zasada subsydiarności jako klucz do reform ustroju administracyjnego państw Europy Środkowej i Wschodniej (na przykładzie Polski), (w:) D. Milczarek, Subsydiarność, Warszawa 1998, s. 126, czy A. Wiktorowska, Zasada subsydiarności, (w:) Instytucje współczesnego prawa administracyjnego. Księga jubileuszowa Profesora zw. dra hab. J. Filipka, red. I. Niżnik-Dobosz i in., Kraków 2001, s. 761-763. 
stwu, ale można określić tendencję, zgodnie z którą zadania te mają być rozdzielone. Zasada, służąc określeniu regulacyjnej roli państwa, odnosi się także do podziału zadań z zakresu ochrony środowiska między organy tej administracji, a zwłaszcza do przekazywania tych zadań jednostkom samorządu terytorialnego. Jak wskazuje M. Górski ${ }^{30}$, w dziedzinie ochrony środowiska ulega ona dość wyraźnym ograniczeniom, uznawanym za niezbędne do osiągnięcia zakładanych celów. Ograniczenia te, jak podkreśla Autor, polegają na uznaniu konieczności takiego lokowania w strukturach organizacyjnych pewnych grup zadań, które służyć ma zapewnieniu określonej, niezbędnej jednolitości celów podejmowanych działań oraz zasad ich prowadzenia.

Drugim, zasadniczym kryterium podziału zadań jest zasada realizacji interesu publicznego. Zadaniem ustawodawcy jest rozważenie, wyważenie i uwzględnienie zróżnicowanych, społecznie doniosłych interesów, potrzeb oraz dążeń społecznych $^{31}$. Przy czym należy wyróżnić interesy społeczności lokalnych oraz interesy ogólnospołeczne ${ }^{32}$. W doktrynie istnieje zgodność co do tego, że rozgraniczenie zadań z zakresu administracji publicznej na zadania lokalne i ogólnospołeczne jest skomplikowane, a samorządy wkraczają niejednokrotnie w sprawy ogólnopaństwowe (na różnych zasadach) i synchronizują zadania lokalne z zadaniami państwa. Charakter lokalny mają sprawy, które wpływają w zasadniczy sposób na warunki życia oraz interesy społeczności lokalnej i mogą być przez nią kształtowane lub można też powiedzieć, mają źródło w lokalnej społeczności albo odnoszą się szczególnie do niej. Jak wskazuje M. Stahl ${ }^{33}$, zadanie można uznać za lokalne, jeżeli oprócz cechy lokalności zadanie przekazywane władzy lokalnej spełnia jeszcze cechę celowości, możności jego realizacji i finansowania oraz egzekwowania odpowiedzialności. Wszystkie przekazywane zadania o charakterze lokalnym, czy to na zasadzie zadań własnych, czy zleconych, mają charakter publiczny i zarazem „państwowy” w tym sensie, że gdyby samorządu nie było - zadania te musiałyby być realizowane przez organy państwa ${ }^{34}$.

Pomimo iż ochrona środowiska jest jednocześnie problemem globalnym, krajowym, regionalnymi i lokalnym ${ }^{35}$, jest celem publicznym, a zadaniem administracji publicznej jest realizacja normatywnie wytyczonego celu publicznego. Ponad-

30 M. Górski, W poszukiwaniu modelu..., op. cit., s. 179.

31 M. Wyrzykowski, Pojęcie interesu społecznego w prawie administracyjnym, Warszawa 1986, s. 174.

32 Podział ten wywodzony jest $z$ teoretycznego przeciwstawienia interesowi publicznemu interesu indywidualnego, Ibidem, s. 31.

33 M. Stahl, Poszukiwania modelu władzy i administracji lokalnej w Polsce, Łódź 1989, s. 112-113 i wskazana literatura. Interes lokalny jest częstokroć inny niż interes ogólnopaństwowy, nie oznacza to, zdaniem niektórych przedstawicieli doktryny, że jest mniej ważny. Takie założenie prowadzi do postawienia tezy o istnieniu „obiektywnego" interesu lokalnego samorządu terytorialnego. Por. B. Dolnicki, Samorząd terytorialny, Warszawa 2016, S. 24.

34 M. Stahl, Poszukiwania modelu..., op. cit., s. 119.

35 L. Gardjan-Kawa, Organy samorządu lokalnego jako podmioty odpowiedzialne za stan środowiska, (w:) M. Górski, M. Stahl, J.P. Tarno (red.), Administracja i prawo administracyjne..., op. cit., s. 69. 
to jest to zadanie ogólnospołeczne, wykonywane w interesie całego społeczeństwa, a dopiero w drugiej kolejności w interesie społeczności lokalnych ${ }^{36}$. Niestety, teza ta nie do końca znajduje odzwierciedlenie w normach zawartych w systemie prawa. Ochrona środowiska została wskazana jako funkcja państwa, określająca zasadnicze kierunki i cele jego działania w art. 5 Konstytucji RP. Faktem jest, że ani obowiązująca ustawa zasadnicza ${ }^{37}$, ani prawo ochrony środowiska ${ }^{38}$, już nie odwołują się do koncepcji środowiska (ani też ziemi) jako dobra ogólnonarodowego. Natomiast zgodnie z art. 3 ustawy z dnia 3 lipca 2001 r. o zachowaniu narodowego charakteru strategicznych zasobów naturalnych $\mathrm{kraju}^{39}$, gospodarowanie zasobami naturalnymi wymienionymi w art. 1, uznanymi za strategiczne (m.in. wody, lasy, kopaliny) jest prowadzone zgodnie $\mathrm{z}$ zasadą zrównoważonego rozwoju w interesie dobra ogólnego. W doktrynie ${ }^{40}$ wyrażono pogląd, że pomimo braku wyraźnego sformułowania środowisko pozostaje niewątpliwie elementem dobra wspólnego.

W opozycji do tych postanowień pozostaje treść art. 7 ust. 1 pkt 1 ustawy o samorządzie gminnym ${ }^{41}$, uznająca zadania z zakresu ochrony środowiska jako zadania własne gminy. Neutralizowanie określonych zagrożeń powodowanych funkcjonowaniem społeczności lokalnych ma charakter lokalny, i choć są to zadania należące do zakresu ochrony środowiska, zostały wskazane przez ustawodawcę odrębnie w art. 7 ust. 1 pkt 3 u.s.g. Zadania z zakresu ochrony środowiska zostały uznane na mocy art. 4 ust. 1 pkt 13 ustawy o samorządzie powiatowym ${ }^{42}$ jako zadania publiczne o charakterze ponadgminnym i przekazane powiatom do ich samodzielnego wykonania. Natomiast zadania określone przez ustawodawcę jako zadania o charakterze wojewódzkim zostały przekazane samorządom województwa (art. 14 ust. 1 pkt 8 ustawy o samorządzie województwa $\left.{ }^{43}\right)$.

Ponadto z punktu widzenia kryterium podziału zadań w oparciu o zasadę realizacji interesu publicznego trzeba zaznaczyć, iż ustawodawca rozróżnia nowe kategorie interesów, obok ogólnopaństwowego i lokalnego - interes ponadgminny i re-

36 Por. M. Górski, Samorząd terytorialny a ochrona środowiska, „Państwo i Prawo” 1993, z. 6, s. 62.

37 Por. art. 12 ust. 2 i 15 pkt 2 Konstytucji Polskiej Rzeczypospolitej Ludowej, tekst jedn. Dz.U. z 1976 r., nr 7 , poz. 36.

38 W preambule ustawy z dnia 30 stycznia 1980 r. o ochronie i kształtowaniu środowiska, tekst jedn. z 1994 r., Dz.U. nr 49, poz. 196 ze zm., potwierdzając funkcje państwa w tym zakresie, ustawodawca odwołał się do koncepcji środowiska jako „dobra ogólnonarodowego”.

39 Ustawa z dnia 3 lipca 2001 r. o zachowaniu narodowego charakteru strategicznych zasobów naturalnych kraju, tekst jedn. z 2018 r., Dz.U., poz. 1235.

40 M. Górski, Komentarz do art. 74 Konstytucji RP..., op. cit., s. 1693 oraz M. Piechowiak, Dobro wspólne jako fundament polskiego porządku konstytucyjnego, Warszawa 2012, s. 371.

41 Ustawa z dnia 8 marca 1990 r. o samorządzie gminnym, tekst jedn. z 2018 r. Dz.U., poz. 994 ze zm., dalej: „u.s.g."

42 Ustawa z dnia 5 czerwca 1998 r. o samorządzie powiatowym, tekst jedn. z 2018 r., Dz.U., poz. 995 ze zm., dalej: „u.s.p."

43 Ustawa z dnia 5 czerwca 1998 r. o samorządzie województwa, tekst jedn. z 2018 r., Dz.U., poz. 996 ze zm., dalej: „u.s.w.” 
gionalny. Jak zauważono $\mathrm{w}$ doktrynie ${ }^{44}$, w konsekwencji oznacza to decentralizację zadań publicznych, ale także decentralizację interesu publicznego. Można mówić o istnieniu interesu publicznego ogólnopaństwowego, jak i interesu publicznego regionalnego, ponadgminnego, czy w końcu gminnego.

\section{Zadania organów samorządu terytorialnego w zakresie prawnej ochrony powierzchni ziemi}

Ustawodawca nie wskazuje kryterium rozgraniczającego zadania samorządu i zadania administracji rządowej. Rozgraniczenie to, jak pisze M. Stahl, jest trudne, umowne i pozbawione cech trwałości ${ }^{45}$. O zakresie samorządu decyduje państwo. Nie powinno jednak robić tego w sposób dowolny, jest ograniczone względami tradycji, racjonalności, wspólnoty interesów osób zamieszkujących określoną jednostkę terytorialną samorządu, obszarem przestrzennym jednostek samorządowych oraz faktyczną możliwością samodzielnego realizowania przypisanych im zadań.

W krajach UE względy historyczne i demograficzne spowodowały istnienie silnych regionów ${ }^{46}$. Regionalizacja jest też uzasadniona tworzeniem się instytucji ponadpaństwowych, potrzebą współpracy międzynarodowej, w tak istotnych dziedzinach jak np. ochrona środowiska, ponadto koniecznością wyrównania różnic w poziomie rozwoju poszczególnych obszarów kraju oraz zmniejszeniem zacofania obszarów słabo rozwiniętych i mających najmniej korzystne warunki rozwoju.

Pojęcie samorządu terytorialnego nie jest jednorodne, ustawodawca w art. 164 ust. 2 Konstytucji RP wyróżnia dwie postaci samorządu terytorialnego: regionalny i lokalny. Odmienność tych instytucji wynika z liczby mieszkańców, szerszej właściwości miejscowej działania, jak też z faktu występowania dualizmu władzy publicznej na szczeblu regionu. Inny jest także rodzaj zadań powierzonych obydwu samorządom: samorząd gminny wykonuje zadania publiczne o charakterze lokalnym, zaś samorządowi regionalnemu przekazano zadania publiczne o charakterze wojewódzkim. Odmienność ta wynika również z istoty „lokalizmu” i „regionalizmu”47, która sprecyzowana została w prawie międzynarodowym, a zwłaszcza w Europejskiej Karcie Samorządu Terytorialnego ${ }^{48}$ oraz w Europejskiej Karcie Samorządu Regionalnego ${ }^{49}$. W ostatnim z wymienionych dokumentów podkreślono, że inaczej ski, M. Stahl, J.P. Tarno (red.), Administracja i prawo administracyjne..., op. cit., s. 352. M. Stahl, Zakres działania gmin - zagadnienia ogólne..., op. cit., s. 10. sza, Rozwój regionalny zagadnienia instytucjonalne, „Samorząd Terytorialny” 2000, z. 10, s. 3.

L. Gardjan-Kawa, Organy samorządu lokalnego..., op. cit., s. 72.

Podpisana w 1985 r. w Strasburgu, ratyfikowana przez Polskę w 1994 r., Dz.U. nr 124, poz. 607.

A. Pakuła, Interes publiczny i użyteczność publiczna jako kategoria zadań samorządu terytorialnego, (w:) M. Gór-

Szerzej: J. Szreniawski, Wstęp do prawa administracyjnego, Część ogólna, Lublin 1992, s. 88-90 oraz M. Kule-

Podpisana w 1997 r. w Strasburgu, nieratyfikowana przez Polskę. Por. M. Kulesza, Rozwój regionalny..., op. cit., s. 3 i B. Dolnicki, Samorząd terytorialny..., op. cit., s. 194-197. 
niż samorząd lokalny, który ma zajmować się sprawami interesu miejscowego, do samorządu regionalnego mają zaś należeć sprawy interesu ogólnego.

W zakresie czynności administracyjnych, których celem jest ochrona środowiska wielopłaszczyznowość interesu publicznego prowadzi niekiedy do kolizji między ogólnym a lokalnym pojmowaniem tego zjawiska ${ }^{50}$. Dlatego przekazywanie zadań jednostkom samorządu terytorialnego powinno uwzględniać, obok możliwości realizacji tych zadań, także prawdopodobieństwo równoważenia interesów lokalnych zbiorowości z interesem ogólnospołecznym. In aliis verbis, musi dojść do kompromisu realizacji zasady pomocniczości z zasadą ochrony interesu publicznego.

\subsection{Zadania powierzone organom samorządu województwa}

Przeprowadzone w Polsce w ostatnim trzydziestoleciu reformy samorządowe spowodowały zasadnicze przesunięcie odpowiedzialności za stan środowiska ze struktur administracji rządowej na organy administracji samorządowej. Powstanie dualizmu władzy na szczeblu województwa również nie pozostało bez wpływu na kształtowanie się regionalnej polityki ekologicznej oraz wzajemnych relacji administracji rządowej i samorządu wojewódzkiego w tym zakresie. W 2005 r. w związku ze zmianami w podziale zadań i kompetencji administracji terenowej ${ }^{51}$, wiele zadań w zakresie ochrony powierzchni ziemi, przypisanych dotychczas wojewodzie, przekazano samorządowi województwa.

Pierwszą grupą zadań powierzonych samorządowi województwa są zadania o charakterze organizatorskim. Jak wskazuje A. Barczak ${ }^{52}$, biorąc pod uwagę treść i sposób określenia tych zadań, nie może być im przypisana typowa cecha lokalności, bowiem ich celem jest urzeczywistnianie założeń ogólnych w ochronie środowiska, które muszą być podejmowane w interesie ogólnospołecznym. Oznacza to, że w pierwszej kolejności realizowane są problemy ogólnospołeczne, a dopiero później lokalne. Wśród zadań o charakterze organizatorskim zasadniczą rolę pełnią instrumenty planistyczne ${ }^{53}$. W tym zakresie najważniejsze znaczenie mają samorządowe programy ochrony środowiska. Przejawem regionalizacji zadań administracyjnych jest powierzenie samorządowi województwa kompetencji do opracowania aktów

50 O pojęciu konfliktu interesów (rozumianego jako układ wzajemnych wartości lub potrzeb, w którym wartości te wykluczają się bądź też realizacja jednych utrudnia realizację innych) pisał M. Wyrzykowski, Pojęcie interesu..., op. cit., s. 159 i n., czy A. Niewiadomski, Publicznoprawny i prywatnoprawny konflikt interesów na przykładzie Europejskiej Sieci Ekologicznej Natura 2000, Warszawa 2017, s. 52-58. Lokalizacja składowiska odpadów, zgodnie z szeroko rozumianym interesem publicznym (np. względy epidemiologiczne), poza granicami miast z tych przyczyn narusza interes mieszkańców gminy, na obszarze której znajduje się składowisko. Utworzenie obszaru ochrony przyrody (np. parku krajobrazowego, obszar Natura 2000) uzasadnione interesem publicznym, przynosi znaczne ograniczenia gospodarcze mieszkańcom tych terenów, naruszając tym samym interes lokalny, por. L. Gardjan-Kawa, Administrowanie zasobami środowiska po reformie ustrojowej, Warszawa 2000, s. 35.

51 Ustawa z dnia 29 lipca 2005 r. o zmianie niektórych ustaw w związku ze zmianami w podziale zadań i kompetencji administracji terenowej, Dz.U. nr 175, poz. 1462 ze zm.

52 A. Barczak, (w:) A. Barczak, E. Kowalewska, Zadania samorządu terytorialnego w ochronie środowiska. Aspekty materialne i finansowe, Warszawa 2015, s. 51-52, 86. 
programowych wyznaczających cele i kierunki rozwoju województwa. Na podstawie art. 11 ust. 2 pkt 5 u.s.w. ustawodawca powierzył mu prowadzenie polityki rozwoju województwa, na którą składa się m.in. racjonalne korzystanie z zasobów przyrody oraz kształtowanie środowiska naturalnego, zgodnie z zasadą zrównoważonego rozwoju. Samorząd określa strategię rozwoju województwa, która uwzględnia w szczególności zachowanie wartości środowiska kulturowego i przyrodniczego, przy uwzględnieniu potrzeb przyszłych pokoleń oraz kształtowanie i utrzymanie ładu przestrzennego (art. 11 ust. 1 pkt 4 i 5 u.s.w.). Realizacja strategii województwa dokonuje się poprzez programy rozwoju, regionalne programy operacyjne, programy służące realizacji umowy partnerstwa i kontrakty terytorialne. Na mocy art. 17 p.o.ś. samorząd województwa opracowuje wojewódzki program ochrony środowiska, uwzględniając m.in. cele zawarte w strategii. Stąd istotne jest, by w sposób prawidłowy rozpoznawał potrzeby ochrony środowiska i planował inwestycje poprawiające jego stan.

Do istotniejszych zadań samorządu województwa należy obowiązek uwzględniania w planach zagospodarowania przestrzennego województw wymagań ochrony środowiska (w szczególności systemu obszarów chronionych, w tym obszarów ochrony środowiska, przyrody i krajobrazu kulturowego oraz granic terenów zamkniętych i ich stref ochronnych), ustalonych w strategii województwa oraz rekomendacje i wnioski z opracowywanego raz na dwadzieścia lata audytu krajobrazowego (art. 39 ust. 3 pkt 2 i 7 w zw. z art. 38a - 38b ustawy z dnia 27 marca 2003 r. o planowaniu i zagospodarowaniu przestrzennym ${ }^{54}$ ).

Do tej grupy zadań zaliczymy możliwość utworzenia w drodze uchwały sejmiku obszaru ograniczonego użytkowania dla przedsięwzięcia mogącego zawsze znacząco oddziaływać na środowisko, lub dla zakładów czy innych obiektów (np. składowiska odpadów, kompostowni, oczyszczalni ścieków), gdzie jest eksploatowana instalacja kwalifikowana jako takie przedsięwzięcie (art. 135 ust. 2 p.o.s.s.) ${ }^{55}$. Możliwość utworzenia obszaru można także zaliczyć do instrumentów pośredniej ochrony powierzchni ziemi.

W zakresie ochrony powierzchni ziemi samorząd województwa posiada uprawnienia o charakterze reglamentacyjno-zobowiązującym. Stosownie do art. 7 ust. 2 i 4 ustawy z dnia 3 lutego 1995 r. o ochronie gruntów rolnych i leśnych ${ }^{56}$ marszałek województwa wyraża zgodę na zmianę przeznaczenia gruntów leśnych niestanowiących własności Skarbu Państwa oraz dołącza także swoją opinię do wniosku o zmianę przeznaczenia dotyczącego dwóch innych kategorii gruntów: gruntów rolnych

\footnotetext{
54 Ustawa z dnia 27 marca 2003 r. o planowaniu i zagospodarowaniu przestrzennym, tekst jedn. z 2018 r. Dz.U., poz. 1945 ze zm., dalej: „u.p.z.p.”

55 Szerzej na ten temat: B. Rakoczy, Komentarz do art. 135 p.o.ś., (w:) J. Ciechanowicz-McLean, Z. Bukowski, B. Rakoczy, Prawo ochrony środowiska. Komentarz, Warszawa 2008, s. 277. 
stanowiących użytki rolne klas I-III (gdy zgodę wyraża minister właściwy do spraw rolnictwa) i gruntów leśnych stanowiących własność Skarbu Państwa (które wymaga zgody ministra właściwego do spraw środowiska). Wskazane zadania marszałka należą do zadań własnych samorządu województwa.

Marszałek województwa ma możliwość, w szczególnie uzasadnionym przypadku, odstąpienia od wymogu przedkładania odpowiednich rozwiązań wariantowych i uzasadnienia ekonomicznego zmiany przeznaczenia gruntu (art. 10 ust. 4 u.o.g.r.l.) oraz uprawnienie do zwolnienia, zgodnie z art. 9 ust. 3 u.o.g.r.l., z generalnego zakazu wznoszenia budynków w lasach ochronnych, poza cele określone w ustawie, w przypadkach uzasadnionych ważnymi względami społecznymi i brakiem innych gruntów.

Do zadań reglamentacyjnych należy uprawnienie marszałka do umorzenia należności i opłat rocznych oraz jednorazowego odszkodowania za przedwczesny wyrąb drzewostanu w przypadku inwestycji o charakterze użyteczności publicznej (np. z zakresu oświaty, wychowania, kultury, ochrony zdrowia), jeżeli inwestycja ta służy zaspokojeniu potrzeb lokalnej społeczności, jeżeli obszar podlegający wyłączeniu nie przekracza 1 ha i nie ma możliwości zrealizowania inwestycji na gruncie nieobjętym ochroną (art. 12 ust. 16 u.o.g.r.l.) $)^{57}$.

Marszałek województwa może, na wniosek organu wykonawczego jednostki samorządu terytorialnego, umorzyć całość lub część należności i opłat rocznych w odniesieniu do gruntów rolnych w przypadku inwestycji zmierzającej do osiągnięcia celów, o których mowa w art. 6 ustawy z dnia 21 sierpnia 1997 r. o gospodarce nieruchomościami ${ }^{58}$, przeznaczonej na cele inne niż określone w art. 12 ust. 16 u.o.g.r.l., jeżeli obszar gruntu podlegający wyłączeniu nie przekracza 1 ha i nie ma możliwości zrealizowania inwestycji na gruncie nieobjętym ochroną.

Ze środków budżetu województwa (art. 20 ust. 2 u.o.g.r.l.), w zakresie ustalonym w u.o.g.r.l., finansowane są: ochrona, rekultywacja i poprawa jakości gruntów rolnych oraz wypłata odszkodowań przewidzianych ustawą (art. 15 ust. 2 i 3 u.o.g.r.l.). Po formalnej likwidacji Funduszu Ochrony Gruntów ${ }^{59}$, dochody związane $\mathrm{z}$ wyłączaniem $\mathrm{z}$ produkcji gruntów rolnych pobierane na podstawie ustawy (opłaty roczne, opłaty z tytułu niewykonania obowiązku zdjęcia i wykorzystania próchnicznej warstwy gleby, należności i opłaty roczne podwyższone oraz odsetki z tytułu należności i opłat) stanowią dochód samorządu województwa gromadzony

$57 \quad$ Na temat szczególnych zasad dotyczących wymiaru i spłaty zobowiązań finansowych z tytułu wyłączenia gruntów: M.A. Król, Obowiązki wynikające z ochrony powierzchni ziemi, (w:) P. Korzeniowski (red.), Prawa i obowiązki przedsiębiorców w ochronie środowiska. Zarys encyklopedyczny, Warszawa 2010, s. 391.

58 Tekst jedn. z 2018 r., Dz.U. poz. 2284 ze zm.

59 Ustawą z dnia 27 sierpnia 2009 r. - Przepisy wprowadzające ustawę o finansach publicznych (Dz.U. nr 157, poz. 1241) dodano rozdział regulujący kwestie związane z wyłączeniem z produkcji gruntów rolnych, uchylono zaś regulujący funkcjonowanie Funduszu Ochrony Gruntów Rolnych. Nowelizacja obowiązuje od 1 stycznia 2011 r. 
przez zarząd na wyodrębnionym rachunku bankowym. Zadania realizowane dotychczas przez fundusz stały się zadaniami własnymi samorządu województwa. W konsekwencji właścicielowi, którego grunty ze względu na ochronę przed erozją lub ruchami masowymi ziemi zostały wyłączone z produkcji, przysługuje zwrot kosztów zakupu niezbędnych nasion i sadzonek ze środków budżetu województwa lub odszkodowanie, jeżeli wyłączenie to spowodowało szkody. Część zadań marszałka województwa, które były zadaniami z zakresu administracji rządowej, stało się zadaniami własnymi samorządu województwa. Marszałek województwa jest wierzycielem i organem egzekucyjnym uprawnionym do egzekucji należności za zobowiązania z tytułu dochodów.

Organy samorządu województwa zostały wyposażone również w uprawnienia kontrolne. Marszałek województwa jest organem kontrolnym w stosunku do przepisów u.o.g.r.l. z wszelkimi wynikającymi z niej uprawnieniami (art. 26 ust. 1 i 2 u.o.g.r.l.).

Należy natomiast stwierdzić, iż ustawodawca polski nie powierzył samorządowi województwa zadań wprowadzanych na szczeblu regionu w kilku państwach UE, np. w Holandii, Niemczech i Hiszpanii. Organy samorządu regionalnego w Holandii uzyskały ważne kompetencje już w 1982 r., w pierwszej holenderskiej regulacji odnoszącej się do problemu zanieczyszczenia powierzchni ziemi ${ }^{60}$. Na tej podstawie holenderskie prowincje opracowały pięcioletnie programy rekultywacji najbardziej skażonych gruntów w granicach obszaru ich władzy terytorialnej (art. 2-7) wraz z rocznym programem współpracy władz samorządowych. Program zawierał harmonogram prac związanych $\mathrm{z}$ badaniem, a następnie $\mathrm{z}$ oczyszczaniem miejsc skażonych. Organy prowincji mogły zobowiązać właścicieli do współpracy w programach oczyszczania oraz przywracania gruntów do stanu właściwego oraz do zaprzestania działalności powodującej skażenia powierzchni ziemi. W szczególnie uzasadnionych wypadkach przepisy przewidywały możliwość wywłaszczania nieruchomości, jeśli mogłoby to ułatwić oszacowanie skażeń oraz procesy remediacji (art. 11) ${ }^{61}$. Programy opracowane przez prowincje były przedkładane do publicznej aprobaty. Refundacja kosztów została podzielona między państwo i budżety lokalne (art. 17-20) ${ }^{62}$. Podobnie ustawa z dnia 3 lipca 1987 r. o ochronie ziemi ${ }^{63}$ przyznała wiele zadań i kompetencji organom prowincji. Władający powierzchnią ziemi są obowiązani do informowania organów prowincji o wszystkich występujących skażeniach i podejmowanych środkach. Zarząd prowincji prowadzi rejestr za-

60 The Soil Clean-up Interim Act of 29 December 1982, (Interimwet bodemsanering), Stb. 1982, nr 763.

61 Por. J.A. Schlickman, T.M. McMahon, N. van Riel, International environmental law and regulation, Sidney and Austin, 1991, s. Neth-28.

62 Feasibility study on possible national and/or European actions in the field of soil protection, raport przedstawiony przez delegację belgijską na VI Europejskiej Ministerialnej Konferencji poświęconej środowisku naturalnemu, Bruksela, 11-12 października 1990, s. 18. 
nieczyszczeń powierzchni ziemi, podejmuje decyzje o przeprowadzeniu badań poziomu zanieczyszczeń i obowiązku przeprowadzenia remediacji (art. 27-29), czy uznaniu zaistnienia poważnego skażenia, z którymi wiąże się wiele obowiązków zobowiązująco-reglamentacyjnych (art. 30-31).

Na mocy niemieckiej ustawy o ochronie ziemi ${ }^{64}$, organy na poziomie regionalnym (landy) zostały zobowiązane do przeprowadzania badań poziomu skażeń w celu poszukiwania miejsc zanieczyszczonych lub podejrzanych o zanieczyszczenie $^{65}$ (art. 11). Na podstawie badań władze landu opracowują plan remediacji, któremu mogą nadać charakter wiążący (art. 13-14). Władze landów zostały ponadto zobowiązane do monitorowania stanu terenów, na których istnieje wysokie prawdopodobieństwo zanieczyszczenia. Podobnie w niektórych prowincjach Hiszpanii regionalne plany zagospodarowania przestrzennego są środkiem ochrony powierzchni ziemi. Plan regionu Navarry ${ }^{66}$ z 1987 r. ograniczał procesy urbanizacyjne na zalesionych obszarach terenów podmokłych oraz na gruntach o wysokiej bądź średniej rolniczej produkcyjności.

W konkluzji należały stwierdzić, iż zadania samorządu województwa w zakresie ochrony powierzchni ziemi są nadal nieliczne, ale trzeba je uznać za znaczące. Samorząd jest przede wszystkim dysponentem środków finansowych pochodzących z należności i opłat, decyduje o sposobie wydatkowania środków i kolejności przeprowadzania działań rekultywujących, podejmuje decyzje o charakterze reglamentacyjnym i służącym przywracaniu do właściwego stanu. Trzeba w tym miejscu zauważyć, że te uprawnienia dotyczą jedynie tych części powierzchni ziemi, które zaliczono do gruntów rolnych, $\mathrm{z}$ uwagi na pełnione funkcje produkcyjne $\mathrm{w}$ rolnictwie.

\subsection{Zadania powierzone organom powiatu}

Szczeblem pośrednim między samorządową wspólnotą mieszkańców (gminą) a regionalną wspólnotą samorządową (województwem) jest powiat. Jak wskazuje J. Szreniawski ${ }^{67}$, powiat stanowi drugi szczebel samorządu terytorialnego, przejmujący kompetencje dawnych rejonów administracyjnych i w pewnym sensie pierwszy szczebel administracji rządowej (zadania z zakresu administracji rządowej wykonywane przez starostę oraz zespolone z nim służby, inspekcje i straże powiatowe).

Powołanie tego szczebla przyczynić się miało do realizacji zadań ponadgminnych, wykraczających poza możliwości podstawowych jednostek samorządu, in-

\footnotetext{
64 Gesetz zum Schutz des Bodens (Bundes-Bodenschutzgesetz) vom 17. März 1998, BGBI. IS. 502 oraz rozporządzenie wykonawcze Bundes-Bodenschutz- und Altlastenverordnung (BBodSchV) von 12. Juli 1999.

65 W niemieckiej ustawie określane jako: Altlasten - historyczne zanieczyszczenie powierzchni ziemi i altlastverdächtige Flächen - potencjalne historyczne zanieczyszczenie powierzchni ziemi.

66 Navarra Planning Regulations for the Protection and Use of Land Regional Act No. 6/1997.

67 Por. J. Szreniawski, Wstęp do prawa..., op. cit., s. 89.
} 
dywidualizację programów, zmniejszenie zakresu administracji centralnej. Powiat, poprzez działalność swoich organów: radę powiatu, ale przede wszystkim zadania powierzone staroście, wykonuje określone ustawami zadania publiczne o charakterze ponadgminnym.

Na szczebel powiatu ustawodawca przekazał liczne zadania o charakterze organizatorskim, poprzez które organy podejmują działania wpływające bezpośrednio na stan powierzchni ziemi. Zaliczyć do nich można uchwalenie powiatowego programu ochrony środowiska (art. 17-18 p.o.ś.) oraz utworzenie w drodze uchwały rady powiatu obszaru ograniczonego użytkowania dla zakładów lub innych obiektów, niewymienionych w art. 135 ust. 2 p.o.ś. (dla których taki obszar tworzy sejmik województwa). Uprawnienie ustanowione dla rady powiatu jest przejawem dyskrecjonalnej władzy tego organu, podejmowanym w procesie stanowienia prawa. Jak wskazuje B. Rakoczy ${ }^{68}$, nie istnieją instrumenty prawne obligujące organy prawodawcze powiatu do podjęcia stosownej uchwały. Pomimo że ustawodawca nie przesądził wyraźnie kwestii prawnego charakteru uchwały o utworzeniu obszaru ograniczonego użytkowania, w orzecznictwie ${ }^{69} \mathrm{i}$ doktrynie ${ }^{70}$ wyrażany jest zgodnie pogląd, iż stanowią one źródło prawa miejscowego.

Jak wskazuje A. Kaźmierska-Patrzyczna ${ }^{71}$, najważniejszym organem z zakresu ochrony gruntów rolnych i leśnych jest starosta. Zadania związane z ochroną tej kategorii gruntów wykonywane są jako zadania zlecone z zakresu administracji rządowej (art. 5 ust. 2 u.o.g.r.l.). Należy ocenić, iż przyjęcie takiego rozwiązania ma głębokie uzasadnienie, służy bowiem ochronie interesu publicznego. Jak wskazał NSA w wyroku z 2007 r. ${ }^{72}$ bezwzględny obowiązek rekultywacji nie jest indywidualnym uprawnieniem właściciela danego gruntu, lecz prawem podmiotowym o charakterze publicznym, wynikającym z art. 74 Konstytucji RP. Zatem starosta wydając decyzje w tym zakresie, przede wszystkim chroni interes publiczny, leżący u podstaw ustawowej ochrony gruntów rolnych i leśnych, jako dobra publicznego.

Organy powiatu posiadają znaczące kompetencje władcze w zakresie reglamentacji korzystania z powierzchni ziemi oraz nakładania określonych obowiązków

68 B. Rakoczy, Postępowanie w sprawie ustanowienia obszaru ograniczonego użytkowania w prawie polskim, „Prawo i Środowisko" 2013, z. 2, s. 61.

69 WSA w Gliwicach w wyroku z dnia 24 sierpnia 2009 r., II SA/GI 139/09, CBOSA wskazał, że nie ulega wątpliwości, iż zaskarżona uchwała stanowi akt prawa miejscowego, ma ona bowiem charakter generalny oraz abstrakcyjny. Prawem miejscowym nazwano uchwałę Rady Powiatu w Poznaniu z dnia 8 lutego 2012 r. nr XV/124/ IV/2012 w przedmiocie utworzenia obszaru ograniczonego użytkowania dla drogi wojewódzkiej, zob.: wyrok WSA w Poznaniu z dnia 5 września 2012 r., IV SA/Po 458/12, CBOSA. Sąd podkreślił, że uchwała w sprawie utworzenia obszaru ograniczonego użytkowania podlega kontroli jako akt prawa miejscowego, o charakterze generalnym oraz abstrakcyjnym.

70 M. Bar, Komentarz do art. 135 p.o.ś, (w:) M. Górski, M. Pchałek, W. Radecki i in., Prawo ochrony środowiska. Komentarz, Warszawa 2011, s. 581 oraz K. Gruszecki, Prawo ochrony środowiska. Komentarz, Warszawa 2016, s. 366-367.

71 A. Kaźmierska-Patrzyczna, Gospodarowanie zasobami geosfery, (w:) M. Górski, Prawo ochrony środowiska, Warszawa 2014, s. 472.

72 Wyrok z dnia 2 kwietnia 2007 r., II OSK 1018/06, Legalis 170571. 
dotyczących ochrony tego komponentu. Do kompetencji starosty należy wydanie decyzji wyłączającej grunty z produkcji rolnej, leśnej i wyrażającej zgodę na odstępstwa lub zwolnienia związane z wyłączeniem gruntów rolnych z produkcji (art. 11 ust. 1 u.o.g.r.l.).

Do tej kategorii zadań należy również wydawanie decyzji nakładającej opłaty i należności związane $\mathrm{z}$ wyłączeniem ${ }^{73}$. Starosta może także nałożyć w drodze decyzji obowiązek zdjęcia oraz wykorzystania na cele poprawy wartości użytkowej gruntów próchnicznej warstwy gleby z najwyższych klas bonitacyjnych gruntów rolnych klas I, II, IIIa, IIIb, III, IVa, IV oraz z torfowisk (art. 14 ust. 1 u.o.g.r.l.). Nałożenie obowiązku zdjęcia próchnicznej warstwy gleby w założeniach ustawodawcy miało pierwotnie odmienny od współczesnego charakter. Zarówno pierwsza polska regulacja ustawowa w zakresie ochrony gruntów rolnych i leśnych z $1971 \mathrm{r} .{ }^{74}$ jak i ustawa z $1982 \mathrm{r}^{75} \mathrm{z}$ uwagi na zasadniczy cel ochrony powierzchni ziemi jako środka produkcji w rolnictwie ${ }^{76}$, nakładała obligatoryjny obowiązek zdjęcia próchnicznej warstwy gleby, na koszt wyłączającego grunty z produkcji rolnej. W założeniu ustawodawcy zdjęcie tej najcenniejszej warstwy gleby miało służyć poprawie wartości użytkowej innych, mniej żyznych gruntów.

W ustawie z 1995 r. nałożenie w drodze decyzji starosty obowiązku zdjęcia próchnicznej warstwy gleby ma charakter fakultatywny. W. Radecki ${ }^{77}$ wskazuje, że decyzja ta ma charakter uznaniowy i musi uwzględniać interes społeczny. A zatem jeśli uzasadnione względy ochrony gruntów rolnych przemawiają za wykorzystaniem próchnicznej warstwy gleby, regułą powinno być nakładanie takiego obowiąz$\mathrm{ku}$, po zasięgnięciu opinii wójta (burmistrza, prezydenta miasta). Praktyka w tym zakresie wygląda inaczej. Jak wskazują J. Bieluk, D. Łobos-Kotowska ${ }^{78}$, powołując się na dane $\mathrm{z}$ raportu $\mathrm{NIK}^{79}$, w przeważającej liczbie spraw nie występowano do wójtów o opinię w sprawie wydawania decyzji zawierającej wskazany obowiązek. Trzeba zauważyć, że w odróżnieniu od wcześniejszej regulacji, obecnie obowiązujący przepis art. 14 ust. 2 u.o.g.r.l., w razie niewykonania obowiązku zdjęcia wskazanej warstwy gleby, nakłada na starostę powinność wydania decyzji zobowiązującej do uiszczenia opłaty ${ }^{80}$ za niewykonanie wskazanego obowiązku przez zobo-

Szerzej na temat wymiaru opłat i należności: M.A. Król, Obowiązki wynikające z ochrony powierzchni ziemi, (w:) P. Korzeniowski (red.), Prawa i obowiązki..., op. cit., s. 390.

74 Art. 15 ust. 1 ustawy z 26 października 1971 r. o ochronie gruntów rolnych i leśnych oraz rekultywacji gruntów, Dz.U. Nr 27, poz. 249 ze zm.

75 Art. 20 ust. 1 ustawy z dnia 26 marca 1982 r. o ochronie gruntów rolnych i leśnych, Dz.U. z 1982 r. nr 111, poz. 79 ze zm., dalej jako „ustawa z 1982 r.” op. cit.

76 Szerzej: M.A. Król, Wpływ regulacji prawno-rolnej na zakres korzystania z gruntu rolnego, „Studia Prawno-Ekonomiczne" 2005, t. LXXII, s. 108-122.

77 W. Radecki, Ustawa o ochronie gruntów rolnych i leśnych. Komentarz, Warszawa 2012, s. 163.

78 J. Bieluk, D. Łobos-Kotowska, Ustawa o ochronie gruntów rolnych i leśnych. Komentarz, Warszawa 2015, s. 122.

79 Informacja o wynikach kontroli, Wyłączanie gruntów z produkcji rolniczej i jego skutki dla ewidencji podatkowej w gminach w latach 2007-2012, NIK 2012 r., P/11/141, nr ewid. 156/2012/P11141/L, s. 4.

80 W. Radecki określa te opłaty jako rodzaj sankcji za niewykonanie obowiązku określonego w art. 14 ust. 1 u.o.g.r.l., W. Radecki, Ustawa o ochronie..., op. cit., s. 164. 
wiązanego lub niewłaściwe wykorzystanie próchnicznej warstwy gleby. A to daje podstawę do ustanowienia kolejnego obciążenia z tytułu wyłączenia gruntów z produkcji.

Ze względu na ochronę gleb przed erozją i ruchami masowymi ziemi, w ramach kompetencji reglamentacyjno-zobowiązujących starosty dano możliwość podjęcia decyzji nakazującej zalesienie, zadrzewienie czy zakrzewienie gruntów lub założenie trwałych użytków zielonych (art. 15 ust. 2 u.o.g.r.l.).

Należy stwierdzić, że w zakresie jakościowej ochrony gruntów nastąpiła zmiana właściwości organu. Na podstawie art. 23 ust. 1 i 2 ustawy z 1982 r. organowi gminy przekazano podejmowanie działań przeciwdziałających erozji gleb i innym zjawiskom powodującym trwałe pogorszenie wartości użytkowej gruntów rolnych. W obecnie obowiązującej ustawie przeciwdziałanie erozji jest zadaniem powierzonym staroście (zadania zlecone z zakresu administracji rządowej), natomiast wójtowi przekazano zadania o charakterze zobowiązującym, które będą podejmowane w wypadku wystąpienia innych form degradacji (art. 15 ust. 5 u.o.g.r.l.) i będą miały na celu przywrócenie wartości użytkowych gruntom. Zastanowienia wymaga przekazanie części tych zadań staroście. Powodem, dla którego dokonano takiego przesunięcia zadań, może być wzgląd na znaczenie problemu erozji gleb (problem o charakterze ogólnospołecznym, a nie lokalnym) lub też ujemna ocena praktyki na gruncie poprzedniej regulacji w tym zakresie.

Kolejną grupę zadań powierzonych staroście stanowią zadania o charakterze bezpośrednio wykonawczym. Jak wskazuje A. Barczak ${ }^{81}$, w zakresie ochrony powierzchni ziemi zadania te prowadzone są w sposób jednorazowy, mają charakter incydentalny i podejmowane są wówczas, gdy pojawi się konieczność podjęcia działań naprawczych. W obrębie tego typu zadań można wyróżnić obowiązek dokonania rekultywacji zdegradowanego gruntu. Starosta jest zobowiązany do przeprowadzenia rekultywacji na cele rolnicze gruntów położonych na obszarach rolniczej przestrzeni produkcyjnej, zdewastowanych lub zdegradowanych przez nieustalone osoby lub w wyniku klęsk żywiołowych oraz gruntów leśnych i gruntów przeznaczonych do zalesienia, a także innych niewymienionych gruntów (art. 20 ust. 2 i 2a u.o.g.r.l.). Starosta w drodze decyzji, po zasięgnięciu opinii określonych podmiotów, m.in. wójta (burmistrza, prezydenta miasta ${ }^{82}$ określa osobę obowiązaną do rekultywacji gruntów, stopień ograniczenia lub utraty wartości użytkowej gruntów,

81 A. Barczak, (w:) A. Barczak, E. Kowalewska, Zadania samorządu..., op. cit., s. 61.

82 Zgodnie ze stanowiskiem wyrażonym w orzecznictwie sądowym (m.in. wyrok NSA z dnia 25 sierpnia 2017 r., II OSK 3022/15, Legalis 1689079; wyrok WSA w Lublinie z dnia 19 kwietnia 2011 r., II SA/Lu 87/11, Legalis 341969 czy wyrok WSA w Krakowie z dnia 31 stycznia 2008 r., II SA/Kr 915/07, Legalis 110211) opinia ta jest formą zajęcia stanowiska, nie ma jednak charakteru wiążącego i starosta nie jest związany treścią zajętego stanowiska przez przywoływane podmioty. 
kierunek i termin wykonania rekultywacji gruntów oraz uznaje rekultywację gruntów za zakończoną.

Można także wyróżnić grupę zadań o charakterze nadzorczo-kontrolnym. Zadania te przewidziane zostały zarówno w odniesieniu do ochrony powierzchni ziemi przed zanieczyszczeniami, przeciwdziałania ruchom masowym ziemi, jak i w odniesieniu do jakościowej ochrony gruntów rolnych. Na tej podstawie starosta:

1) dokonuje identyfikacji potencjalnych historycznych zanieczyszczeń powierzchni ziemi (art. 101 d p.o.ś.), ustalając działalność mogącą z dużym prawdopodobieństwem powodować historyczne zanieczyszczenie powierzchni ziemi, listę substancji powodujących ryzyko, ale także analizę dostępnych informacji na temat zagrożenia zanieczyszczeniem gleby lub ziemi i wykonanie pierwszego etapu badań zanieczyszczenia. Starosta sporządza wykaz potencjalnych historycznych zanieczyszczeń powierzchni ziemi, dokonując co 2 lata jego aktualizacji. Jednakże to regionalny dyrektor ochrony środowiska wydaje decyzję w sprawie planu remediacji w odniesieniu do zanieczyszczonych gruntów, a w sytuacji zanieczyszczenia gruntów wykorzystywanych na cele rolne, tylko po zasięgnięciu opinii starosty (art. 1011 ust. 5 pkt 7 p.o.ś.);

2) prowadzi rejestr zawierający podstawowe informacje o terenie, w tym w zakresie obserwacji terenów zagrożonych ruchami masowymi ziemi (art. 110a ust. 1 p.o.ś.);

3) monitoruje stan gruntów rolnych poprzez zapewnienie przeprowadzania co 3 lata badań poziomu skażenia gruntów (art. 18 ust. 1 u.o.g.r.l.);

4) ma uprawnienie do wstępu na teren władającego powierzchnią ziemi w celu wykonywania badań zanieczyszczenia gleby i ziemi (art. 101d ust. 3-5 p.o.ś.). Władający powierzchnią ziemi, na wniosek starosty, przekazuje wszelkie znajdujące się w jego posiadaniu informacje dotyczące potencjalnego historycznego zanieczyszczenia powierzchni ziemi oraz jego możliwych źródeł.

Ze sprawowaniem kontroli wiąże się obowiązek przeciwdziałania stwierdzonym sytuacjom niezgodnym z przepisami prawa, przede wszystkim poprzez zastosowanie opłat sankcyjnych niezależnych od kar przewidzianych w p.o.s..$^{83}$ (np. podwyższone opłaty za wyłączenie gruntów z produkcji bez decyzji zezwalającej na wyłączenie, za niewykonanie obowiązku rekultywacji lub niezakończenie rekultywacji w terminie - art. 28 u.o.g.r.l.). W zakresie uprawnień kontrolnych staroście przysługuje prawo: wstępu na teren, przeprowadzenia badań, pobierania próbek (co 
służy realizacji uprawnień z art. 28 u.o.g.r.l.) oraz kontroli stosowania przepisów u.o.g.r.l. (art. 26 ust. 1 u.o.g.r.l.).

Staroście przysługują też uprawnienia, które określa się mianem ,raportingu". Starosta prowadzi sprawozdawczość z zakresu obszaru gruntów wyłączonych z produkcji, ustalonych opłat z tytułu wyłączenia gruntów, gruntów zdewastowanych podlegających rekultywacji, a także wyników rekultywacji i zagospodarowania gruntów oraz danych dotyczących złóż torfowych (art. 33 u.o.g.r.l.).

Trzeba podkreślić, że starosta jako zwierzchnik administracji rządowej w powiecie wykonuje swoje uprawnienia w stosunku do zespolonych na szczeblu powiatu służb i inspekcji, które nie tracą swojego rządowego charakteru. Jedną z nich jest powiatowa inspekcja sanitarna ${ }^{84}$. W zakresie ochrony powierzchni ziemi można wskazać wiele zadań powierzonych inspekcji, ale na szczeblu województwa (m.in. uzgadnianie projektów miejscowych planów zagospodarowania przestrzennego, studium uwarunkowań i kierunków zagospodarowania przestrzennego gminy oraz ustalanie warunków zabudowy i zagospodarowania terenu pod względem wymagań higienicznych i zdrowotnych). Powiatowy inspektor uzgadnia jedynie dokumentację projektową pod względem wymagań higienicznych i zdrowotnych.

Jak zauważono w literaturze przedmiotu ${ }^{85}$, współcześnie kompetencjami w zakresie ochrony środowiska obciążony jest przede wszystkim starosta, który jako organ administracji ogólnej odpowiada za bezpieczeństwo ekologiczne w granicach swojej właściwości miejscowej. Należy zauważyć, że staroście powierzono bardzo liczne $\mathrm{i}$ istotne $\mathrm{z}$ punktu widzenia ochrony powierzchni ziemi zadania, ale znaczna ich część to zadania powierzone z zakresu administracji rządowej. Trzeba też wyraźnie zaakcentować, że powołując w $2014 \mathrm{r}^{86}$ remediację, jako nowy instrument ochrony powierzchni ziemi, ustawodawca przekazał kilka zadań i kompetencji organowi administracji rządowej - Generalnemu Dyrektorowi Ochrony Środowiska, znakomitą ich część regionalnym dyrektorom ochrony środowiska (art. 101c-101p p.o.ś.), zaś bardzo nieliczne staroście (art. 1011 ust. 5 pkt 7 p.o.ś.).

\subsection{Zadania powierzone organom gminy}

Powołanie w 1998 r. dwóch nowych szczebli samorządu terytorialnego nie zmieniło, co do zasady, odpowiedzialności i zakresu kompetencji gmin w zakresie ochrony środowiska. Potwierdzeniem tej tezy jest m.in. art. 4 ust. 6 u.s.p., który stanowi, że zadania należące do powiatu nie mogą naruszać zakresu działania gmi-

Państwowy powiatowy inspektor sanitarny jako kierownik powiatowej inspekcji sanitarnej wchodzi w skład zespolonej administracji rządowej w powiecie (art. 10 ust. 1 pkt 3 ustawy z dnia 14 marca 1985 r. o Państwowej Inspekcji Sanitarnej, tekst jedn. Dz.U. z 2017, poz. 1261 ze zm.). sów ustawy Prawo ochrony środowiska, Prawo i Środowisko 2002, z. 3, s. 95.

86 Ustawa z dnia 11 lipca 2014 r. o zmianie ustawy - Prawo ochrony środowiska oraz niektórych innych ustaw, Dz.U. z 2014 r., poz. 1101. 
ny. Gmina jako jednostka samodzielna wykonuje zadania publiczne w imieniu własnym i na własną odpowiedzialność, co wzmacnia domniemanie kompetencji gminy we wszystkich sprawach publicznych mających charakter lokalny, a nie zastrzeżonych na rzecz innych organów (art. 6 u.s.g.).

Do zadań własnych gminy, wymienionych $\mathrm{w}$ art. 7 ust. 1 u.s.g., należy grupa zadań o charakterze organizatorskim, służących zapewnieniu ładu przestrzennego i ekologicznego (gospodarka terenami, ochrona środowiska). Jest to najogólniej sformułowane zadanie w zakresie organizacji życia mieszkańców na danym terytorium, warunkujące równocześnie podejmowanie dalszej, już bardziej szczegółowo konkretyzowanej działalności. Cytowanemu postanowieniu ustawy o samorządzie gminnym logicznie odpowiadają przyznane organom gminy kompetencje w zakresie m.in. uchwalania studium uwarunkowań i kierunków zagospodarowania przestrzennego oraz miejscowych planów zagospodarowania przestrzennego. Organy gminy, przyjmując wskazane akty zagospodarowania przestrzennego, wpływają na szeroko rozumianą gospodarkę gruntami. Wśród gruntów objętych planowaniem są różne kategorie, a oddziaływanie to powinno się odbywać, na mocy art. 72 ust. 1 pkt 1 i 4-6 oraz art. 74 ust. 1 p.o.ś. z zapewnieniem warunków utrzymania równowagi przyrodniczej i racjonalnej gospodarki zasobami środowiska, w szczególności poprzez ustalanie programów racjonalnego wykorzystania powierzchni ziemi oraz zapewnienie oszczędnego korzystania z terenu, a także uwzględnienie: 1) konieczności ochrony gleby i ziemi przed zanieczyszczeniem w związku z prowadzeniem gospodarki rolnej; 2) potrzeb w zakresie zapobiegania ruchom masowym ziemi; 3) innych potrzeb w zakresie ochrony gleb, ziemi.

Jak twierdzi J. Ciechanowicz ${ }^{87}$, egzemplifikacja zadań własnych gminy poczyniona w art. 7 ust. 1 u.s.g. wskazuje na to, czym gminy mogą się zajmować, lecz nie stanowi wyraźnie, o czym gminy mogą decydować. Wynika to dopiero z przepisów materialnego prawa administracyjnego, które określają szczegółowo treść i przedmiot ich kompetencji. Aby ustalić rolę samorządu gminnego w zakresie ochrony powierzchni ziemi, należy dokonać analizy przepisów kilku ustaw szczegółowych, bowiem - jak wynika z przeprowadzanych badań - nie wszystkie sprawy z zakresu ochrony środowiska o charakterze lokalnym należą wyłącznie do właściwości samorządu gminnego.

Do organizatorskich zadań gminy zaliczymy instrument o charakterze uchwałodawczym, będący typowym aktem planowania, podejmowany przez radę gminy jako zadanie własne, jakim jest plan gospodarowania na gruntach położonych na obszarach ograniczonego użytkowania, istniejących wokół zakładów przemysłowych (art. 16 u.o.g.r.l.). W planie powinny być określone m.in. rodzaje występujących za-

87 J. Ciechanowicz, Kompetencje samorządu terytorialnego w zakresie ochrony i kształtowania środowiska, „Ruch Prawniczy, Ekonomiczny i Socjologiczny" 1991, z. 2, s. 99. 
nieczyszczeń, wpływ zanieczyszczeń na istniejący sposób zagospodarowania czy wysokość przewidywanych odszkodowań z tytułu obniżenia poziomu produkcji lub zmiany kierunku produkcji (art. 16 ust. 2 u.o.g.r.l.).

Najistotniejszym problemem pozostaje kwestia stopnia samodzielności gminy w zakresie możliwości zmiany przeznaczenia gruntów rolnych i leśnych na cele nierolnicze i nieleśne ${ }^{88}$. Organy gminy nadal mają niewielkie kompetencje władcze w tym zakresie, bo zgodę na przeznaczenie gruntów rolnych na cele nierolnicze wyrażają, w większości przypadków, organy administracji rządowej (minister właściwy do spraw rozwoju wsi, minister właściwy do spraw środowiska - art. 7 ust. 2 pkt 1 i 2 u.o.g.r.l.) oraz w jednym przypadku marszałek województwa (art. 7 ust. 2 pkt 5 u.o.g.r.l.). Wójt (burmistrz, prezydent miasta) posiada możliwość realizowania działań zmierzających do racjonalnego wykorzystania gruntów, jako strona w postępowaniu o zmianę przeznaczenia gruntu ${ }^{89}$, występuje $\mathrm{z}$ wnioskiem o wyrażenie zgody do właściwego organu (art. 7 ust. 3 u.o.g.r.l.).

Należy ocenić, że zakres obowiązku uzyskania zgody określonego organu administracji w stosunku do gruntów rolnych i leśnych uległ wyraźnemu ograniczeniu. Natomiast proces przeznaczania gruntów leśnych na cele nieleśne w zasadniczym swym zakresie nie uległ zmianie. W każdym przypadku planowanego przeznaczenia, bez względu na jego cel czy powierzchnię gruntu leśnego, wymagane jest uzyskanie zgody właściwego organu.

Zobowiązująco-reglamentacyjny charakter mają te zadania, w których organ gminy (wójt, burmistrz lub prezydent) może zobowiązać właściciela gruntów do wykonania w określonym terminie odpowiednich zabiegów, w razie wystąpienia z jego winy degradacji gruntów rolnych (innych niż erozje, ale spowodowanych np. nieprzestrzeganiem przepisów o ochronie roślin uprawnych poprzez nadmierne stosowanie środków ochrony roślin). W razie niewykonania decyzji organ zleca wykonanie zastępcze na koszt właściciela, z wykorzystaniem do tego czasu środków budżetu województwa (art. 15 ust. 5 u.o.g.r.l.). Natomiast właścicielom gruntów położonych na obszarze ograniczonego użytkowania, prowadzącym produkcję w sposób niezgodny z ustaleniami planu gospodarowania na tym obszarze, wójt (burmistrz, prezydent miasta), ale w porozumieniu z państwowym wojewódzkim inspektorem sanitarnym, nakazuje zniszczenie określonych upraw i przemieszczenie zwierząt (art. 16 ust. 5 u.o.g.r.l.).

Wójt (burmistrz, prezydent miasta) posiada również uprawnienia opiniodawcze, m.in. wydaje opinię o podjęciu decyzji w sprawie rekultywacji (art. 22 ust. 2

Zwiększenie stopnia samodzielności gminy nastąpiło już poprzez samo przyjęcie rozwiązania w ustawie o ochronie gruntów rolnych i leśnych z 1995 r., że przeznaczenie gruntu rolnego na cele nierolnicze dokonywane jest jedynie $w$ ramach planów zagospodarowania przestrzennego. 
pkt 3 u.o.g.r.l.), a także o nałożeniu obowiązku zdjęcia i wykorzystania próchnicznej warstwy gleby (art. 14 ust. 1 u.o.g.r.l.). Można też wskazać uprawnienia kontrolne gminy do przestrzegania przepisów ustawy o ochronie gruntów (art. 26 ust. 1 u.o.g.r.1.).

Zadania i kompetencje gminy w zakresie ochrony powierzchni ziemi są nieliczne. Obok tradycyjnych zadań z zakresu policji administracyjnej, czyli zapewnienia ładu i bezpieczeństwa publicznego, gminie powierzono zadania mające na celu zaspokajanie zbiorowych potrzeb gminnej wspólnoty samorządowej, wsparte poprzez istnienie domniemania właściwości gminy w sprawach publicznych o znaczeniu lokalnym. Gminy otrzymały wiele nowych zadań, do których należy także ochrona środowiska. Jak zauważa J. Ciechanowicz ${ }^{90}$, uznanie ochrony środowiska za zadanie własne gminy w ustawie o samorządzie gminnym jest tylko wytyczną i nie znajduje odzwierciedlenia w ustawodawstwie ochronnym. Zasadnicze znaczenie trzeba przyznać uprawnieniom gminy, które odnoszą się do zagospodarowania przestrzennego. W wyniku decentralizacji i komunalizacji zadań w tym zakresie, gmina uzyskała samodzielność planistyczną, do jej zadań własnych należy bowiem ustalenie przeznaczenia i zasad zagospodarowania terenu ${ }^{91}$. Dlatego też racjonalne gospodarowanie i wykorzystanie zasobów powierzchni ziemi zależy w znacznej mierze od gmin. W zakresie ochrony gruntów rolnych, uprawnienia planistyczne, jak i ochronne, gminy są ograniczone, co wskazywałoby, iż nadal ochrona gruntów rolnych jest realizowana w interesie ogólnospołecznym.

\section{Wnioski}

Przeprowadzona analiza pozwala postawić kilka wniosków. Ustawodawca uznaje prawną ochronę i racjonalne gospodarowanie zasobami powierzchni ziemi za realizację interesu publicznego. Racjonalność działania wymaga nie tylko uwzględnienia rachunku ekonomicznego, ale także ekologicznego czy potrzeb społecznych. Za działania racjonalne będą uznane te działania organów administracji, które uwzględniają realizację interesu publicznego w skali ogólnonarodowej, a nie tylko interesów lokalnych.

Realizacja konstytucyjnego obowiązku ochrony środowiska oraz prowadzenia polityki zapewniającej bezpieczeństwo ekologiczne spoczywa przede wszystkim na organach administracji publicznej. Ustawodawca stanął przed problemem pogodzenia potrzeb i wymogów samodzielności oraz odpowiedzialności społeczności lokalnych w wykonywaniu zadań, z koniecznością ochrony interesu społecznego, ochroną niepomnażalnych dóbr środowiska, jakimi są zasoby powierzchni zie-

90 J. Ciechanowicz, Prawna ochrona środowiska. Wybrane zagadnienia, Gdańsk 1992, s. 55.

91 Por. na ten temat: R. Hauser, E. Mzyk, Z. Niewiadomski, M. Rzażewska, Ustawa o zagospodarowaniu przestrzennym z komentarzem i przepisami wykonawczymi, Warszawa 1995, s. 4. 
mi, a zwłaszcza grunty rolne i leśne. Przeprowadzone badania ukazują złożoność czynników przesądzających o wyborze organu, który ma efektywnie wykonywać zadania ochronne. Przekazanie kompetencji określonemu organowi administracji rządowej czy samorządowej jest wynikiem kompromisu między realizacją procesu decentralizacji zadań publicznych, zgodnie z zasadą proporcjonalności a ochroną interesu publicznego. Natomiast wybór szczebla samorządu zależy od uznania, czy zadanie to służy działaniu na rzecz interesu lokalnego, czy też jest to interes szerszy, ponadgminny, regionalny. Niemałe znaczenie ma przy tym możliwość efektywnego działania w omawianym zakresie, czemu służą przyznane jednostkom samorządu instrumenty prawne, pozwalające na wykonanie nałożonych obowiązków. W świetle obowiązującego stanu prawnego, samorząd terytorialny odgrywa istotną rolę w zapobieganiu powstawania zmian powierzchni ziemi oraz przywracaniu jej do stanu właściwego. Realizacja zadań przez poszczególne szczeble samorządu wywiera pożądany wpływ na ochronę tego zasobu nie tylko w skali lokalnej, ale i regionalnej. Zapoczątkowane w 1990 r., a kontynuowane w 1998 i 2005 roku cedowanie zadań z zakresu ochrony powierzchni ziemi samorządowi terytorialnemu pozwala stwierdzić, że w przypadku samorządu województwa są one doniosłe, chociaż nieliczne. Najpoważniejsze zadania we wskazanym zakresie, zwłaszcza w odniesieniu do ochrony gruntów rolnych i leśnych powierzono staroście, ale są to zadania zlecone z zakresu administracji rządowej. Zadania przekazane gminie mają głównie charakter organizatorski i dotyczą kwestii służących zapewnieniu ładu przestrzennego i ekologicznego.

Zatem należy stwierdzić, że przekazywanie zadań samorządom nie odbywa się automatycznie. Nadal ustawodawca pozostawił istotne zadania w gestii organów administracji rządowej, zarówno na szczeblu centralnym, jak i terenowym. W tym miejscu trzeba zauważyć powierzenie w 2014 r. kolejnych, nowych zadań w zakresie prawnej ochrony powierzchni ziemi organom administracji rządowej. Dotyczy to instrumentów wprowadzonych po raz pierwszy do polskiego systemu prawa, przede wszystkim w zakresie remediacji, ale i występowania historycznych zanieczyszczeń powierzchni ziemi. Odmiennie niż w Holandii czy Niemczech, gdzie zadania te powierzono organom samorządu na szczeblu regionalnym, w naszym kraju, jak należy sądzić kierując się zasadą ochrony interesu publicznego, w zasadniczej części ustawodawca przekazał je organom rządowej, niezespolonej administracji w województwie - regionalnym dyrektorom ochrony środowiska. 


\section{LOCAL GOVERNMENT TASKS IN THE RANGE OF LEGAL SOIL PROTECTION}

Keywords: local government tasks, soil protection, agricultural and forest land protection, principle of subsidiarity, principle of public interest

The soil, and in particular agricultural and forest land, is the basic natural resource, conditioning all other existing resources. Protection of that resource and its functions has been delegated to both government and local government authorities. The aim of this research is to analyze tasks and competences entrusted to local government units in solving issues related to soil protection and identifing and evaluating the adopted criteria for protective tasks division between three levels of the local government.

\section{Bibliografia:}

Bar M., Komentarz do art. 135 p.o.ś., (w:) M. Górski, M. Pchałek, W. Radecki i in., Prawo ochrony środowiska. Komentarz, Warszawa 2011.

Barczak A., (w:) A. Barczak, E. Kowalewska, Zadania samorządu terytorialnego w ochronie środowiska. Aspekty materialne i finansowe, Warszawa 2015.

Bieluk J., Łobos-Kotowska D., Ustawa o ochronie gruntów rolnych i leśnych. Komentarz, Warszawa 2015.

Boć J., (w:) Konstytucje Rzeczypospolitej oraz komentarz do Konstytucji RP z 1997 r., J. Boć (red.), Wrocław 1998.

Borkowski J., Określenie administracji i prawa administracyjnego, (w:) System prawa administracyjnego, J. Starościak (red.), t. I, Wrocław 1977.

Ciechanowicz J., Kompetencje samorządu terytorialnego w zakresie ochrony i kształtowania środowiska, „Ruch Prawniczy, Ekonomiczny i Socjologiczny” 1991, z. 2.

Ciechanowicz J., Prawna ochrona środowiska. Wybrane zagadnienia, Gdańsk 1992.

Complak K., (w:) J. Boć (red.), Konstytucje Rzeczypospolitej oraz Komentarz do Konstytucji RP z 1997 roku, Wrocław 1998.

Derlatka M., Garlicki L., Komentarz do art. 74 Konstytucji RP, (w:) L. Garlicki, M. Zubik, Konstytucja Rzeczpospolitej Polskiej. Komentarz, t. II, Warszawa 2016.

Dolnicki B., Koncepcja województwa samorządowego, „Samorząd Terytorialny” 1999, z. 6.

Dolnicki B., Samorząd terytorialny, Warszawa 2016.

Environmental principles and concepts, OCDE/GD(95)124, OECD Paris 1995.

Feasibility study on possible national and/or European actions in the field of soil protection, raport przedstawiony przez delegację belgijską na VI Europejskiej Ministerialnej Konferencji poświęconej środowisku naturalnemu, Bruksela, 11-12 października 1990.

Gardjan-Kawa L., Administrowanie zasobami środowiska po reformie ustrojowej, Warszawa 2000.

Gardjan-Kawa L., Organy samorządu lokalnego jako podmioty odpowiedzialne za stan środowiska, (w:) M. Górski, M. Stahl, J.P. Tarno (red.), Administracja i prawo administracyjne u progu 
trzeciego tysiąclecia. Materiały konferencji naukowej katedr prawa i postępowania administracyjnego, Łódź 2000.

Global Environmental Outlook GEO4 - Environment for development, UNEP 2007.

Górski M., Komentarz do art. 74 Konstytucji RP, (w:) M. Safjan, L. Bosek (red.), Konstytucja RP. Komentarz, t. I, Art. 1-86.

Górski M., Rola państwa w ochronie środowiska, „Organizacja. Metody. Technika” 1990, z. 8-9.

Górski M., Samorząd terytorialny a ochrona środowiska, „Państwo i Prawo” 1993, z. 6.

Górski M., W poszukiwaniu modelu administrowania sprawami ochrony środowiska, (w:) Między tradycją a przyszłością w nauce prawa administracyjnego. Księga jubileuszowa dedykowana Profesorowi Janowi Bociowi, J. Supernat (red.), Wrocław 2009.

Górski M., Wydawanie aktów administracyjnych jako prawna forma dopuszczenia do korzystania z zasobów środowiska - propozycje de lege ferenda, „Studia Prawno-Ekonomiczne” 1994, t. L.

Górski M., Zarządzanie sprawami ochrony środowiska, (w:) Prawo ochrony środowiska, M. Górski (red.), Warszawa 2018.

Gruszecki K., Prawo ochrony środowiska. Komentarz, Warszawa 2016.

Hauser R., Mzyk E., Niewiadomski Z., Rzażewska M., Ustawa o zagospodarowaniu przestrzennym z komentarzem i przepisami wykonawczymi, Warszawa 1995.

Informacja o wynikach kontroli, Wyłączanie gruntów z produkcji rolniczej i jego skutki dla ewidencji podatkowej w gminach w latach 2007-2012, Najwyższa Izba Kontroli 2012, P/11/141, nr ewid. 156/2012/P11141/L.

Izdebski H., Samorząd terytorialny. Podstawy ustroju i działalności, Warszawa 2014.

Jastrzębski L., Prawo ochrony środowiska w Polsce, Warszawa 1980.

Kaźmierska-Patrzyczna A., Gospodarowanie zasobami geosfery, (w:) M. Górski, Prawo ochrony środowiska, Warszawa 2014.

Król M.A., Obowiązki wynikające z ochrony powierzchni ziemi, (w:) P. Korzeniowski (red.), Prawa i obowiązki przedsiębiorców w ochronie środowiska. Zarys encyklopedyczny, Warszawa 2010.

Król M.A., Wpływ regulacji prawno-rolnej na zakres korzystania z gruntu rolnego, „Studia Prawno-Ekonomiczne" 2005, t. LXXII.

Kulesza M., Rozwój regionalny zagadnienia instytucjonalne, „Samorząd Terytorialny” 2000, z. 10.

Kulesza M., Zasada subsydiarności jako klucz do reform ustroju administracyjnego państw Europy Środkowej i Wschodniej (na przykładzie Polski), (w:) D. Milczarek, Subsydiarność, Warszawa 1998.

Lipowicz I., (w:) J. Boć (red.), Konstytucje Rzeczypospolitej oraz Komentarz do Konstytucji RP z 1997 roku, Wrocław 1998.

Łustacz L., Rola państwa i prawa w ochronie środowiska, (w:) L. Łustacz (red.), Prawo a ochrona środowiska, Ossolineum 1975.

Łustacz L., Rola polityki i prawa w kształtowaniu i ochronie środowiska, (w:) „Studia Iuridica”, t. II. Zagadnienia prawnej ochrony środowiska naturalnego, Wydawnictwo Uniwersytetu Warszawskiego 1974.

Niewiadomski A., Publicznoprawny i prywatnoprawny konflikt interesów na przykładzie Europejskiej Sieci Ekologicznej Natura 2000, Warszawa 2017.

Olejniczak-Szałowska E., (w:) M. Stahl (red.), Prawo administracyjne. Pojęcia, instytucje, zasady w teorii i orzecznictwie, Warszawa 2016. 
Pakuła A., Interes publiczny i użyteczność publiczna jako kategoria zadań samorządu terytorialnego, (w:) M. Górski, M. Stahl, J.P. Tarno (red.), Administracja i prawo administracyjne u progu trzeciego tysiąclecia. Materiały konferencji naukowej katedr prawa i postępowania administracyjnego, Łódź 2000.

Piechowiak M., Dobro wspólne jako fundament polskiego porządku konstytucyjnego, Warszawa 2012.

Rabska T., Pozycja samorządu terytorialnego w konstytucji, „Ruch Prawniczy, Ekonomiczny i Socjologiczny" 1995, z. 2.

Radecki W., Ustawa o ochronie gruntów rolnych i leśnych. Komentarz, Warszawa 2012.

Radwan M., Zasada pomocniczości w polityce regionalnej EWG, „Samorząd Terytorialny” 1993, z. 9.

Rakoczy B., Komentarz do art. 135 p.o.ś., (w:) J. Ciechanowicz-McLean, Z. Bukowski, B. Rakoczy, Prawo ochrony środowiska. Komentarz, Warszawa 2008.

Rakoczy B., Postępowanie w sprawie ustanowienia obszaru ograniczonego użytkowania w prawie polskim, „Prawo i Środowisko” 2013, z. 2.

Regulski J., Nowy ustrój, nowe szanse, nowe problemy, (w:) Materiały Szkoleniowe RAP, z. 1.

Schlickman J.A., McMahon T.M., N. van Riel, International environmental law and regulation, Sidney and Austin, 1991.

Smoktunowicz E., Encyklopedia obywatela PRL, Warszawa 1987.

Smoktunowicz E., Podział ról wśród organów administracji państwowej w zakresie ochrony zasobów i tworów przyrody, „Studia Prawno-Ekonomiczne” 1973, t. XI.

Stahl M., Poszukiwania modelu władzy i administracji lokalnej w Polsce, Łódź 1989.

Stahl M., Samorząd terytorialny a państwo, (w:) M. Stahl, E. Olejniczak-Szałowska, Samorząd terytorialny, Podstawowe zagadnienia, Warszawa 1994.

Stahl M., Zakres działania gmin - zagadnienia ogólne, (w:) M. Stahl (red.), Administracyjnoprawne zadania i kompetencje gmin, Warszawa 1994.

Starościak J., Zagadnienia przemian administracji państwa socjalistycznego, (w:) L. Bar (red.), Studia z dziedziny prawa administracyjnego, Ossolineum 1971.

Steiger H., Określenie celów państwa a ustawa zasadnicza. Z problematyki najnowszego rozwoju politycznego i prawno-konstytucyjnego RFN, „Acta Universitatis Lodziensis. Folia Iuridica” 1988, nr 36.

Swora M., Organizacje pozarządowe a samorząd terytorialny (zagadnienia wybrane), (w:) M. Górski, M. Stahl, J.P. Tarno (red.), Administracja i prawo administracyjne u progu trzeciego tysiąclecia, Materiały konferencji naukowej katedr prawa i postępowania administracyjnego, Łódź 2000 .

Szreniawski J., Wstęp do prawa administracyjnego, Część ogólna, Lublin 1992.

Wiktorowska A., Zasada subsydiarności, (w:) Instytucje współczesnego prawa administracyjnego. Księga jubileuszowa Profesora zw. dra hab. J. Filipka, red. I. Niżnik-Dobosz i in., Kraków 2001.

Wilczyński P., Ochrona środowiska jako samodzielna funkcja administracji samorządowej, (w:) P. Korzeniowski, I. Wieczorek (red.), Reglamentacja korzystania ze środowiska jako funkcja administracji samorządowej, Łódź 2018.

Wyrzykowski M., Pojęcie interesu społecznego w prawie administracyjnym, Warszawa 1986.

Wysocka B., Zadania starosty w świetle przepisów ustawy Prawo ochrony środowiska, Prawo i Środowisko 2002, z. 3.

Zimmermann J., Prawo administracyjne, Warszawa 2018. 